DISLOCACIONES DE LA POESÍA HISPANOAMERICANA: LOS LUGARES DE ENUNCIACIÓN Y ESPACIALIDAD DEL MENSAJE EN LA POESÍA VISUAL DE GUILLERMO DEISLER Y EL NúClEO POST-ARTE

\title{
Disruptions in Latin American Poetry: Places of Enunciation and Spaciality of the Message in Guillermo Deisler's and Nucleo Post- Arte's Visual Poetry
}

\author{
Alejandro Palma Castro \\ Benemérita Universidad Autónoma de Puebla \\ Puebla, México \\ alejandro.palmaffyl@gmail.com \\ GABRIEL HERNÁNDEZ ESPINOSA \\ Benemérita Universidad Autónoma de Puebla \\ Puebla, México \\ gahesz@icloud.com
}

Resumen: tanto Guillermo Deisler como el Núcleo Post-Arte
provienen de dos fuertes tradiciones líricas, la chilena y la mexicana
respectivamente, apegadas a lo verbal como fundamento del discurso
poético. En este trabajo, proponemos que sus lugares de enunciación, así
como otros espacios de expresión del mensaje poético, han implicado un
dislocamiento de lo verbal. A través de una interpretación comparada de
ambos casos, desde la topoiesis de las instancias enunciativas, mostramos
la postura crítica sostenida en el trabajo de estos artistas, en tanto
denuncia de lo verbal como mecanismo de legitimación de la poesía
canónica y de la injusticia social y política. Palabras clave: Guillermo Deisler, Núcleo Post-Arte, topoiesis, discurso poético, poesía visual

\begin{abstract}
Guillermo Deisler from Chile and Núcleo Post-Arte from Mexico are visual poetry artists who belong to strong poetic traditions centered in the verbal. In this article we demonstrate how both artists have disrupted the traditional poetic discourse through new places of enunciation and expression spaces. In a comparative interpretation of both cases of study from the methodological approach titled "topoiesis of the instances of enunciation" we demonstrate the critical position that sustains their work denouncing the verbal as a legitimation mechanism for canonized poetry as well for the social and political injustices.

Keywords: Guillermo Deisler, Núcleo Post-Arte, Topoiesis, Poetic Discourse, Visual Poetry
\end{abstract}


Dentro de la profusa producción poética existente en Hispanoamérica, una parte de esta, la que versa sobre las expresiones figurales y visuales por encima de lo verbal y que denominaremos en ese trabajo de manera general como visualismos, ha sido poco estudiada y apreciada como parte de la tradición poética general. En un trabajo anterior, ya hemos expuesto la situación que guarda este tipo de textos en el panorama crítico:

Tanto los creadores como la crítica literaria insisten en considerar las exploraciones figurativas y visuales en la poesía como un puro divertimento, estrafalario a veces, que desde luego no merece la atención que sí requiere la obra poética inscrita en lo puramente verbal. A pesar de la insistencia horaciana del ut pictura poesis, la literatura occidental en general ha confiado demasiado en su potencia verbal descuidando las ventajas de una dimensión figurada. (Palma, 2011: 165)

A partir del contexto de las neovanguardias artísticas surgidas al final de la Segunda Guerra Mundial, comienza a cobrar importancia, para creadores y críticos, la producción de poemas que involucran otro tipo de dimensiones en el discurso poético, además de la verbal. En su manifiesto "plano-piloto para poesia concreta" (1958), el grupo de poesía concreta de Noigrandes menciona un área lingüística específica, la "verbivoco visual":

que participa das vantagens da comunicação não-verbal, sem abdicar das virtualidades da palabra. com o poema concreto ocorre o fenômeno da metacomunicação: coincidência e simultaneidade da comunicação verbal e não verbal, com a nota de que se trata de uma comunicaçáo de formas, de uma estrutura-conteúdo, não da usual comunicaçấo de mensagens. (Campos, 1958: 157)

Es de importancia notar en esta cita el deslinde que Augusto de Campos y sus copartícipes realizan al respecto de lo verbal, al señalar la evolución crítica en las formas del verso histórico. Si bien su propuesta no se encuentra tan alejada de los technopaegnia helénicos (siglo IV a. C.) y la amplia tradición de los carmina figurata que siguió durante siglos, la gran diferencia vendrá impuesta por un contexto diferente, a saber, el de la modernidad y sus avatares en Occidente. Precisamente, el movimiento de poesía concreta de Brasil resulta una evidencia artística sobre las formas para poder conciliar la modernidad y sus fracasos a mediados del siglo XX. Asimismo, representa la piedra de toque ${ }^{1}$ para el resurgimiento y legitimación del visualismo como expresión poética en Latinoamérica, en el contexto de las neovanguardias. En la presentación de la Primera Bienal Internacional de Poesía Visual y Experimental 1985-1986,

\footnotetext{
${ }^{1}$ Consideramos que el concretismo brasileño representó un momento fundamental en el desarrollo y difusión de los visualismos poéticos en Latinoamérica durante su fase inicial en la década de los cincuenta, porque a pesar de que existían antecedentes en Europa, la labor programática de los hermanos de Campos y Décio Pignatari encabezó una vanguardia internacional que aseguró el clima de auge para la experimentación literaria. Si bien el concretismo fue derivándose hacia un programa artístico muy específico, la producción, circulación y crítica del poema visual quedó enmarcada bajo determinadas prácticas que hoy definen la neovanguardia en el continente.
} 
llevada a cabo por el Núcleo Post-Arte, se puede leer un resumen de las principales influencias que entraron en juego para finales del siglo $\mathrm{XX}$ en Latinoamérica:

El proyecto de la poesía experimental, visual o alternativa hunde sus raíces prehistóricas en la gestualidad y el balbuceo, los ideogramas y jeroglíficos del nacimiento de la escritura. Al paso de los siglos, en los poemas de figuras de la antigüedad clásica y los emblemas, caligramas y la tradición numerológica de la Edad Media y el periodo renacentistabarroco.

En su proyecto moderno arranca de la aspiración romántica a la "integración de las artes" y el poema Un golpe de dados jamás abolirá el azar (1897) de Stéphane Mallarmé. Su marcha es paralela a las "vanguardias históricas" — cubofuturismo, dadaísmo, constructuvismo, etc.- hasta llegar, en los años 50, a la Poesía Concreta y más tarde al Poema/Proceso brasileños, la Poesía Visiva del Gruppo 70 de Florencia y las exploraciones semióticas, informáticas y de telecomunicaciones, así como a los "sucesos" y accionismos de nuestros días.

Su objetivo principal: la crítica de las restricciones e imposiciones del lenguaje lógico discursivo y la recuperación de la "poiesis" como creatividad abierta y búsqueda de nuevas formas simbólico-perceptivas del conocimiento humano. Por ende, la experimentación visual poética constituye una práctica que unifica todas las prácticas anteriores como la pintura, la escritura de la palabra y expresiones gráficas de nuestro siglo, como el collage, o bien la grabación sonora y de video, haciéndolo desde un punto de partida que es el poema-objeto, cuya función última corresponde al destinatario. No el poema en su papel autocontemplativo y de consumo pasivo, sino como un detonador para la lectura y respuesta creativas ante la hora crucial que vivimos. (2)

Además de dichos movimientos, apreciamos también otras propuestas relevantes para los artistas que nos proponemos estudiar. Tal es el caso del Conceptualismo, el cual tiene su referente más temprano en 1961, gracias al ensayo "Concept Art" de Henry Flynt. Posteriormente, Sol LeWit instaura el término "conceptual" para referirse a la desmaterialización del arte, lo cual habría permitido comprenderlo como idea. Por otra parte, el conceptualismo también estuvo ligado al Grupo Fluxus y al Neodadaísmo, con George Maciunas como uno de sus principales exponentes. En Francia, al término de la Segunda Guerra Mundial, se originó el Letrismo con Isidore Isou y el Neorrealismo con Yves Klein a la cabeza. Ahora bien, manera más específica, tanto para Guillermo Deisler como para el Núcleo Post-Arte, el punto de partida de su trabajo son el Arte-Correo y la Poesía Visiva.

La poesía visiva fue un movimiento artístico surgido en 1963, impulsado por Eugenio Miccini y Lamberto Pignotti, quienes forman el Gruppo 70. Fundamentalmente, retoma aspectos futuristas y dadaístas pero centrándose en la preponderancia de la imagen y tratando de crear un lenguaje icónico, además de valerse de los elementos de los medios masivos de comunicación. El uso de este tipo de medios se relaciona con el afán crítico y social del movimiento, de tal manera que ellos son utilizados como método de 
denuncia, resistencia y crítica social. A este movimiento debemos sumar la aparición del Arte Correo, ligado a los artistas conceptuales, en específico con Raymond Edward Johnson, quien en 1953 empieza a mandar obras conceptuales vía postal estableciendo redes que serán fundamentales para el Arte Correo. Gracias a su circulación, se resaltó la importancia del proceso antes que de la materialidad, lo cual dio pie al auge del Art-copy, es decir, de obras creadas a partir de la manipulación de la fotocopiadora. En el caso de Latinoamérica, las redes del Arte Correo propiciaron el reconocimiento de un trabajo común a partir de las publicaciones periódicas de diversos países y del "Primer Encuentro Americano de Poetas" (México D.F., 1964). ${ }^{2}$ Previamente, y aunque de manera aislada, habrá que reconocer el trabajo del argentino Eduardo Antonio Vigo con la revista Diagonal Cero (1961), desde donde se fueron conceptualizando de manera paulatina varios de los experimentos visualistas que se concretarán con el trabajo del uruguayo Clemente Padín en su revista Los Huevos del Plata (1965). De hecho, podemos destacar la labor de Vigo en su revista, en 1964, como la base para iniciar la primera red de Arte Correo hispanoamericano intercambiando textos con Padín o con Guillermo Deisler, quien en ese entonces residía en Antofagasta. A partir de 1969, la red se extendió con los argentinos Luis Camnitzer y Liliana Porter, y en Brasil con Pedro Lyra. Con esta influyente base de producción poético-visual, otros países como México y Chile, donde prevalecía una fuerte tradición lírica de expresión verbal, la incursión en el visualismo implicó una dislocación del discurso poético redefiniendo sus constitutivos formales y evidenciando los procesos de legitimación literaria, al tiempo que comprometió un mensaje de contenido político y social.

Con el fin de demostrar tal dislocación, en este trabajo proponemos revisar dos casos de estudio, Deisler y el Núcleo Post-Arte, desde la perspectiva de la topoiesis de la enunciación. El concepto deriva de la preocupación crítica por establecer criterios que permitan distinguir de manera clara y certera las maneras bajo las cuales cobran significación los distintos tipos de espacio en un texto literario. En "Topoiesis: Procesos de espacialización en la literatura (crítica y metodología)", queda expuesto de la siguiente manera: "Diríamos que la topoiesis define esos espacios, siempre vinculados a un tiempo, que se generan en y alrededor de la creación de un texto que representa una modelización de mundo" (Palma et. al., 2016: 7). Es así como se parte con una propuesta metodológica que, teniendo en cuenta el proceso de comunicación literaria, distingue los ámbitos del enunciador, la producción y difusión material del texto desde su dispositivo, su espacio textual y su recepción. En particular, gracias a la topoiesis de la enunciación esperamos poder interpretar "los mecanismos de poder que legitiman o desautorizan un discurso" (Palma et. al. 2016: 10). Dado que arrancamos con la hipótesis de la dislocación de lo

\footnotetext{
${ }^{2}$ En el número 10 (1964) de la revista El corno emplumado se publicó el manifiesto "Primer encuentro americano de poetas. Declaración de México", como resultado del movimiento Nueva Solidaridad, el cual proponía "la exigencia de una rigurosa conciencia crítica y un trabajo creador, en el sentido del uso del lenguaje auténtico, sin concesiones o dogmas sectarios y convencionales o a actitudes sistematizantes" (114). En esta declaración confluyeron diversos artistas visuales, poetas y editores de revistas del continente americano.
} 
verbal en el discurso poético asentado en Chile y México, nos parece importante describir los principales elementos en los textos de estos artistas para que, como se propone en la "Topoiesis de las instancias enunciativas", podamos demostrar "la interacción establecida entre un locutor y un alocutario [...] enmarcada en una serie de parámetros como la intención, las representaciones psicosociales, los preconstructos culturales, el ethos y las pasiones transpuestos en la argumentación para generar un micro universo particular" (Escobar et al., 2016: 29). Consideramos que los espacios generados por la situación de comunicación planteada en los textos de Deisler y el Núcleo Post-Arte que hemos seleccionado para este artículo, son producto del contexto particular desde el cual han surgido. La comprensión de este último permite una lectura más atenta de su obra, pues como se plantea:

Tanto el autor como el enunciador están situados dentro -o fuera- de cierta geografía, espacio y tiempo, por lo que pueden ser localizados. Entendemos dicha localización como la inserción de un autor, un enunciador, una obra literaria, personaje, etcétera, dentro de contextos espacio-temporales rastreables en la obra y que pueden incidir tanto en su creación como en su posible lectura. (Escobar et. al., "Topoiesis de las instancias enunciativas": 28)

El par de casos de estudio seleccionados presentan similitudes tanto en el contexto de producción, como en su lugar de enunciación y el espacio donde se expresa el mensaje. Además, permiten ser interpretados como una crítica a la hegemonía verbal del discurso poético. En adelante, realizaremos el análisis a la obra del chileno Guillermo Deisler junto con la de César Espinosa y Leticia Ocharán, integrantes del grupo mexicano llamado Núcleo Post-Arte, desde sus principios constructivos, el uso del espacio, su contenido social y la evasión de lo verbal. Esta situación comunicativa vendrá determinada no por un afán experimentador azaroso, sino que atendiendo a un contexto político y social específico, desde donde predomina una desconfianza con lo verbal dado el carácter canónico legitimador con el cual opera la asentada tradición lírica en Chile y México, pero también como una respuesta social y política a la situación de injusticia vivida en dichos países durante la década de los setenta y los ochenta.

La poesía visual y experimental del siglo XX tuvo diversos exponentes en Latinoamérica. En el caso chileno, su primer representante fue Vicente Huidobro, quien junto a autores como Ludwig Zeller, Braulio Arenas y Julio Cáceres (ambos últimos miembros del grupo Mandrágora), Nicanor Parra, Enrique Lihn, Alejandro Jodorowsky (miembros del proyecto Quebrantahuesos), Guillermo Deisler, Juan Luis Martínez, Cecilia Vicuña, Eugenio Dittborn y Raúl Zurita, entre otros, formaron parte de la tradición experimental chilena del siglo XX. El tiempo se ha encargado de situar a estos autores dentro del panorama poético. Cecilia Vicuña es reconocida como una de las mejores poetas experimentales; Juan Luis Martínez escribió-diseñó La novela nueva (1977), la cual se ubicó como una obra canónica en la experimentación chilena; y, por último, Guillermo Deisler ha ido ganando terreno desde 2005, cuando el Fondo de Escritores le rinde un homenaje en el 
cual participó Clemente Padín, además de una exposición de su obra en Valparaíso (2007) y una más en el Museo Nacional de Bellas Artes en Santiago de Chile (2009). Lo anterior quiere decir que existió una laguna en el conocimiento de la obra de Deisler al menos en Latinoamérica, cuestión que, gracias a diversos trabajos de investigación, ${ }^{3}$ así como a la digitalización de su archivo, ${ }^{4}$ va en retroceso.

La obra de Guillermo Deisler (1940-1995), que había comenzado a cobrar notoriedad a finales de la década de los sesenta, sufre una abrupta interrupción cuando ocurre el golpe de Estado del 11 de septiembre de 1973 y la posterior dictadura pinochetista. Este evento de magnitudes trágicas, no solamente para Chile sino para toda Latinoamérica, implica también de manera simbólica un desencanto con la realidad; la esperanza en la transformación socialista vía la elección democrática de pronto se ve frustrada a causa de una maniobra financiada y orquestada por Estados Unidos y a través de la violencia de las fuerzas militares, quienes imponen una nueva realidad política en base a su discurso hegemónico. Este acto genera como consecuencia un ánimo de decepción y desconfianza hacia las instituciones y sus modos de expresión, sobre todo ante el lenguaje escrito como impositor del discurso y la realidad oficial. Aunque la literatura y el arte en general reaccionan en contra de la situación, algunos artistas comienzan a explorar las posibles formas para expresar aquello que supone un rompimiento radical con lo establecido.

Guillermo Deisler fue una persona multifacética. Profesor, poeta, editor y diseñador publicitario, entre otras actividades; inició su trabajo como editor e ilustrador en los años sesenta, sobre todo con su participación en el surgimiento de Ediciones Mimbre, editorial que se encargó de lanzar diversos volúmenes en la década de los sesenta. En 1972 publicó la antología Poesía visiva en el mundo en la mencionada editorial (figura 1), en franca relación con la Poesía Visiva italiana y a la par con los Artefactos de Nicanor Parra, orientados la instalación o al poema objeto antes que en la poesía visual misma. En 1973, Deisler fue encarcelado durante un tiempo y ese mismo año, una vez libre, partió hacia el exilio en Europa. Vivió en Francia, Bulgaria y la República

\footnotetext{
${ }^{3}$ Sin ánimo de proponer un estado de la cuestión sobre los trabajos críticos dedicados a Deisler, queremos mencionar aquellos que nos han sido de gran utilidad para realizar este artículo y que consideramos guía fundamental para el estudio de su obra: Ariel Santibáńez (1971), "La visión mágica de la madera. Los gruñidos de la imagen actual. El libro como unidad artesanal. Guillermo Deisler, al paso", en Tebaida n. ${ }^{\circ}$ 6, pp. 16-18; Andrés Anwandter (2002), "Nota sobre Guillermo Deisler", en Cyber Humanitatis, n. ${ }^{\circ}$ 21. Consultado en <http://web.uchile.cl/vignette/cyberhumanitatisaaa/CDA/vida_sub_simple3/0,1250,PRID\%253D 1093\%2526SCID\%253D1096\%2526ISID\%253D5,00.html> (27 de marzo 2017); Francisca García (2007), "Memoria: EXCLUSIVO HECHO PARA USTED! Obras de Guillermo Deisler", Taller de letras, n. ${ }^{4}$, pp. 179-185; María Inés Zaldívar (2007), "El contexto de Guillermo Deisler en Chile y la generación poética de los 60", Taller de letras n. ${ }^{\circ}$ 41, pp. 109-120; Felipe Cussen (2010), "Instrucciones para leer instrucciones", en Honorato, Paula et. al. (eds.), Notas visuales. Fronteras entre imagen y escritura. Santiago de Chile, Metales Pesados, pp. 167-191; Francisca García (2010), "Puesta en valor de una tradición invisible. Guillermo Deisler y la poesía visual chilena”, Revista Laboratorio, n.o 3. Consultado en <http://revistalaboratorio.udp.cl/num3_2010_art8_garcia/> (27 de marzo 2017).

${ }^{4}$ Su obra puede consultarse en el siguiente sitio electrónico: http://guillermodeisler.cl
} 
Democrática Alemana. La mayoría de su obra a partir de entonces se origina en Plovdiv (Bulgaria) $)^{5}$ y luego en Halle (RDA).

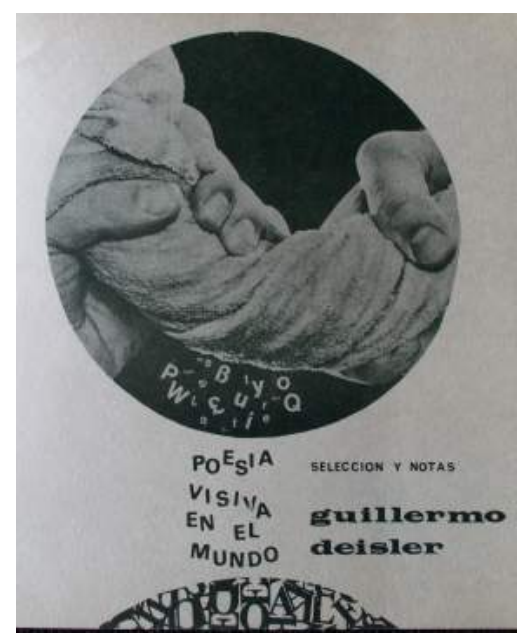

Figura 1: Guillermo Deisler, Portada Poesía visiva en el mundo, Antofagasta, Ediciones Mimbre. Fuente: Archivo Deisler.

Si bien para los sesenta aún Pablo Neruda representaba el canon de la poesía chilena, los visualismos fueron cobrando auge a través del trabajo de Deisler, pero también de otras figuras que redefinieron el curso de la poesía visual en Chile durante ese periodo. Quizás por la importancia que ya implicaba dentro de la poesía chilena, Nicanor Parra se perfila como un antecedente ineludible en la incursión de las experimentaciones literarias derivadas hacia el visualismo. En 1952, Parra participó en el proyecto denominado Quebrantahuesos. Éste consistió en una poesía mural que, ejercida junto a Enrique Lihn y Alejandro Jodorowsky, básicamente se enfocó en la creación de un diario mural hecho con recortes de periódico, es decir, mediante la técnica del collage. En cierto sentido, le dieron continuidad a la obra del grupo surrealista chileno La Mandrágora, sin embargo, las intenciones fueron diferentes, pues el Quebrantahuesos fue concebido para el espacio público, además de inscribirse a una estética pop cuyo objetivo era parodiar las primeras planas de los periódicos de los medios masivos de comunicación de la época.

En 1954 Parra publicó Poemas y antipoemas, lo cual le significó su ascenso como poeta convencional o esencialmente verbal. Así continuó hasta su compilación Obra gruesa (1969), donde ya presenta parodias de los caligramas de Huidobro y su acercamiento al visualismo toma nuevos bríos. Con el Quebrantahuesos y las parodias caligramáticas (Canciones rusas incluido en Obra gruesa), su obra pone en escena otra arista del visualismo, a saber, la instalación; poemas para ser percibidos antes que leídos. En Artefactos (1972),

\footnotetext{
${ }^{5}$ Aunque Deisler ya era considerado en Sudamérica un poeta visual, tras su exilio en Europa, consiguió trabajo como escenógrafo, artista plástico y publicista; un factor determinante para reorientar su labor poética hacia la red europea de arte correo.
} 
incursiona en los denominados poemas objeto, los cuales consisten en otorgar una dimensión simbólica o metafórica a uno o varios objetos tomados de lo cotidiano, des- y re-contextualizándolos para portar un mensaje poético. A su vez, lleva a cabo la migración de soporte en términos similares, pues los Artefactos consistieron en una caja que albergaba 242 tarjetas, semejantes a las postales, que incluían textos e imágenes, e incluso manuscritos de Parra, y al reverso se otorgaba espacio para escribir e incluir datos del destinatario. Este hecho contribuye al cambio en los modos de lectura de la poesía, ya que transgrede no sólo la noción del libro sino que apela, de manera más urgente que la normal, a un conocimiento externo, del contexto, para poder interpretar los artefactos. En esta línea continuó Parra cuando publicó en 1983 CHISTES PARA/PARRA DESORIENTAR A LA POESÍA/POLICÍA, donde, como hiciera Deisler, se acercó a una composición y apreciación colectiva de la poesía, así como a la estética de la Poesía Concreta.

Por otra parte, en 1973, Cecilia Vicuńa publica en Londres su libro objeto Sabor A Mi. Según la misma autora explica en una nota inicial, se trata de un diario de vida que comienza el 24 de junio de ese mismo ańo, cuando el golpe era inminente. La entonces artista plástica decide "hacer todos los días un objeto para sustentar la revolución" (Vicuña, 1973: s/p). Es así como en el texto se encuentran: dibujos, collages, poemas, manifiestos sociales y políticos, fusionados con una postura enunciativa. La pequeña nota introductoria de Felipe Ehrenberg, artista visual mexicano, consignaba: "Sabor A Mi, libro precario y peligroso, es el primer aullido de la conciencia creativa chilena, apareciendo a escasos dos meses de haber sido violado el presente y el futuro chileno [...] del nuevo desorden sistematizado" (Vicuña, 1973: s/p). En efecto, además de la factura artesanal del texto, su "accidental hechura", de acuerdo con Ehrenberg, era un reflejo "del estado de ánimos de Cecilia y de todos los que acompañamos a Chile en estos primeros días de Ley y Orden" (Vicuña, 1973: s/p). Vicuña tenía como antecedente ser una artista plástica que buscaba, en el marco de las experimentaciones neovanguardistas, establecer nuevas sensaciones de lo que implicaba el giro político socialista de Chile. En particular, su exposición "Salón de Otoño" (1971) en el Museo Nacional de Bellas Artes de Santiago de Chile se propone ser: "la experiencia de recepción de la obra como una instancia colectiva y de modificación de la mirada, aludiendo al periodo cuando se hablaba del hombre/mujer nuevo/a (especificación de Vicuña). El carácter revolucionario de la obra es que contribuye a que los sujetos miren su entorno de un modo distinto" (Madrid, 2007: 11). Sabor A Mi es también el diario de obra de dicha exposición, por lo tanto, este libro objeto que combina sus poemas fechados desde 1966 hasta 1971 se manufacturan a través del texto híbrido. Constituye en sí mismo la experiencia que va de la búsqueda de una nueva forma de expresión, acorde con la esperanza de nuevos tiempos, al desencanto por el golpe de Estado. Vicuña busca expresar una complejidad de sensaciones a través de otros soportes y elementos visuales fuera de lo verbal; primero como medio de expresión revolucionario y, luego, como forma de lo incomprensible.

De manera similar opera La nueva novela (1977) de Juan Luis Martínez. Maquinado desde 1968, y rechazado en 1971 por la editorial 
Universitaria, este libro se recompone en el contexto de la esperanza socialista y la posterior incertidumbre que trajo la dictadura militar. En 1977, Martínez decide autoeditarlo con 500 ejemplares distribuidos de manera clandestina en Viña del Mar. Texto considerado excéntrico y hasta incomprensible por la poca crítica que lo pudo leer en el momento, a partir de una edición posterior (1985) habría de llamar la atención. En palabras de Jaime Valdivieso: "Este libro se juega fundamentalmente en el terreno del significante, nos muestra un mundo dislocado" (2001: 56). Gracias a la combinatoria de diversos discursos, como los silogismos, teoremas, fotografías, dibujos, collages, La nueva novela, con un sesgo desde su título, desestabiliza al mundo presente a partir de los fundamentos mismos de la existencia. Por ello, tras hacer un análisis de las solapas donde se pregunta "¿Qué es la realidad? ¿Cuál es la realidad?", Valdivieso sostiene que:

[t]anto el discurso verbal como visual se combinan en una unidad indisoluble. El primero, alterando el orden habitual de todo libro que comienza luego del índice, se inicia en la contratapa donde plantea lo que vendrá a ser una de las claves del libro: el cuestionamiento mismo de la realidad y lo que será el comienzo de una lógica absurda y de una mirada y de un pensamiento que se afirman y a la vez se niegan. (Valdivieso, 2001: 56)

En la actualidad podemos considerar que La nueva novela es una de las obras de la poesía visual y experimental más estudiadas. De ella se han hecho múltiples lecturas, tanto literarias como filosóficas y artísticas, desempolvando temáticas que van: desde el escape a la temporalidad, la semiología en su sistema de citas, el uso consciente de la transtextualidad, hasta el juego con el lector a partir del ocultamiento del autor y las pistas de lectura, cuestión posibilitada por la anulación del significado y la multiplicidad de interpretaciones. ${ }^{6}$

Nelly Richard, en "Una cita limítrofe entre neovanguardia y postvanguardia", propone que la avanzada modernización del arte chileno ha quedado interrumpida luego del golpe de Estado:

La gradual progresión de ese orden se vio bruscamente sacudida, después de 1973, cuando movimientos artísticos, programas estáticos y fuerzas culturales, tuvieron que abandonar la pretensión de entablar mutuas correspondencias de signos porque la interreferencialidad de las series "arte", "sociedad", "cultura", "modernidad", etc. había sido dislocada por los quiebres de la totalidad histórica y política. (Richard: 1994, 37)

\footnotetext{
${ }^{6}$ Es profusa la crítica que se ha escrito sobre la obra de Juan Luis Martínez pero queremos destacar cuatro fuentes que nos han sido de ayuda para este trabajo: Juan Luis Martínez, Enrique Lihn y Pedro Lastra, Señales de ruta. Santiago de Chile: Editorial Archivo, 1987; Oscar Galindo, "El Alfabestiario universal de La nueva novela de Juan Luis Martínez", Revista chilena de literatura, n. 57 (2000): 21-40; Soledad Fariña y Elvira Hernández, Merodeos en torno a la obra poética de Juan Luis Martínez. Santiago: Intemperie, 2001; Scott Weintraub, Juan Luis Martínez's Philosophical Poetics. Lewisburg: Bucknell University Press, 2015.
} 
A través de estas tres obras es evidente que en el contexto particular de los setenta en Chile los visualismos se convierten en una alternativa que funciona como forma expresiva de lo que es el desencanto y desconfianza hacia la realidad imperante. Las incursiones experimentales revolucionarias se transforman, en el caso de Vicuña y Martínez, en una dislocación de la realidad impuesta desde el discurso de la historia oficial. En términos de experimentación poética, para varias tradiciones latinoamericanas la década de los setenta representa un cuestionamiento general a los medios de expresión poéticos, desde la misma concepción de la escritura y el lenguaje, hasta la migración del soporte. En este recorrido, pasan por la concepción colectiva del arte y el uso de los medios de comunicación masiva con un programa artístico. Debido a esta cuestión, el mensaje debía ser rápido y efectivo. En ese sentido, la poesía visual se adaptó al cambio de ritmo de la época, a través de la búsqueda de un mayor alcance en pos de ganar nuevos lectores.

Deisler estará inmerso en este contexto, pues cuestiona la idea de lengua para enfocarse más en un lenguaje cuyo fin es transmitir un mensaje de otras formas. Por otra parte, lleva a cabo la migración de soporte al adscribirse al Arte Correo, donde el libro no es esencialmente necesario, pues se puede trabajar desde una postal a formatos más grandes. Deisler fue de los pocos poetas chilenos que se acercó a una tendencia más visual, además de participar, ya en el exilio, en la red internacional de Arte Correo. Probablemente, por su condición de exiliado aunada a la necesidad de publicar su trabajo en la lengua alemana, llegó a una de las premisas fundamentales del visualismo; la de privilegiar, en términos saussureanos, el lenguaje antes que la lengua. En otras palabras, buscó que la transmisión del pensamiento pudiera fluir sin la necesidad de una lengua en específico, lo cual lleva a la mezcla de códigos, en este caso, el verbal y el visual. Además, pugnó por la realización colectiva de la poesía, lo cual incluyó una mirada crítica al contexto sociocultural de la época.

Ya inscrito en las prácticas del Arte Correo, creó su sello de artista (figura 2), una práctica básica en el mail-art. Uno de sus proyectos más importantes fue la revista-carpeta internacional de poesía visual y experimental Uni/vers (;), la cual contó con treinta y cinco números. Iniciada en 1987, se prolongó hasta 1995 (figuras 3 y 4), debido a la muerte de su autor a causa de un cáncer de huesos. Esta carpeta-revista siempre incluía cuarenta trabajos de poetas de todo el mundo. Deisler contactaba a treinta y nueve artistas, pues él siempre incluía un trabajo propio, y procedía a la elaboración de cien ejemplares, hechos a mano. Cada artista que participaba recibía un ejemplar con las obras de los demás participantes, mientras el resto de ejemplares eran vendidos a coleccionistas particulares o instituciones. A menudo había un hilo conductor; entre los más célebres están el número dedicado a la conmemoración de los 500 años del descubrimiento de América y el número dedicado a la figura de Vicente Huidobro. Muchos de estos trabajos fueron adquiridos por bibliotecas de Francia, España, Alemania y Nueva York. Cabe destacar que esta trayectoria se fraguó en gran parte en Alemania, donde se editó casi la totalidad de su obra. ${ }^{7}$

\footnotetext{
${ }^{7}$ Las imágenes que reproducimos en este artículo, de la figura 1 a la 8, provienen del Archivo
} Deisler. Agradecemos a Laura Coll, viuda de Guillermo Deisler, las facilidades brindadas para 


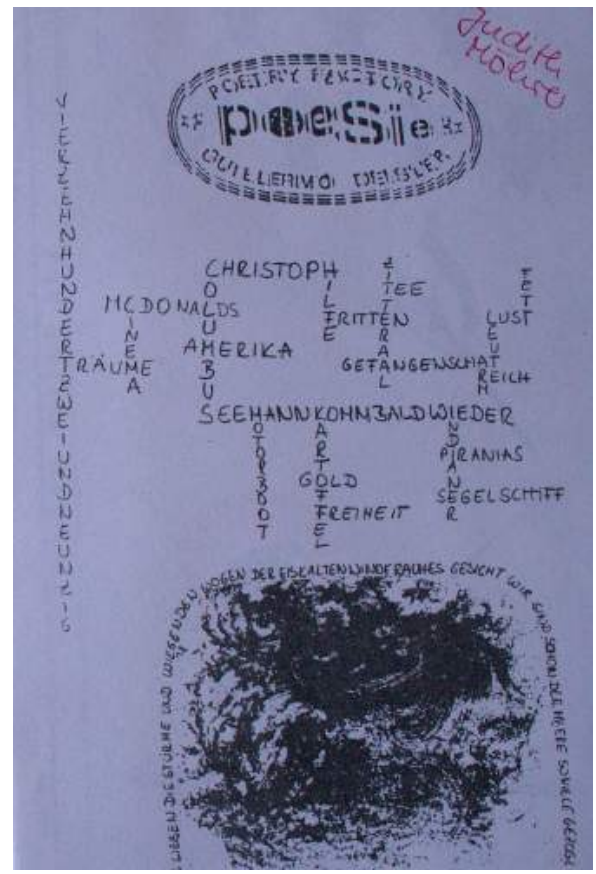

Figura 2: Guillermo Deisler, Ejemplo de Sello de Artista Guillermo Deisler. Fuente: Archivo Deisler.

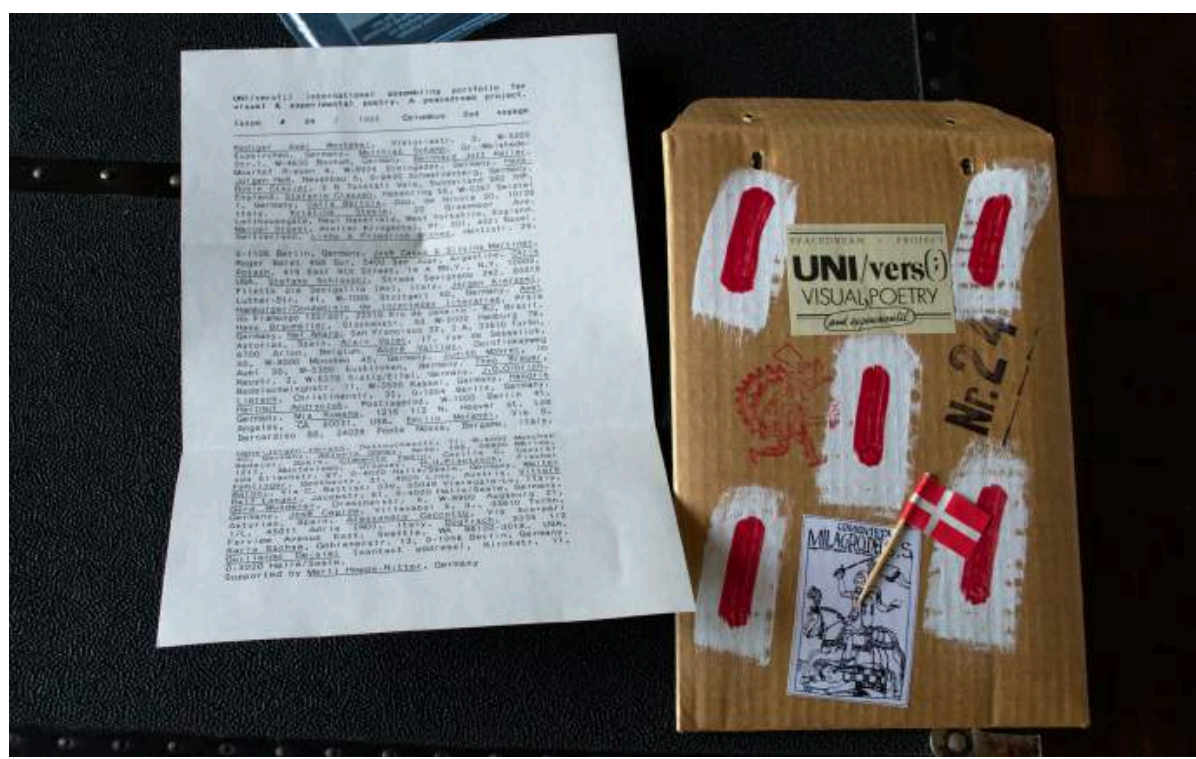

Figura 3: Guillermo Deisler (1993), Uni/vers (;), no. 24, Halle, Edición manual. Fuente: Archivo Deisler.

la visita al archivo, la entrevista que concedió, así como la autorización para el uso de estas imágenes. 


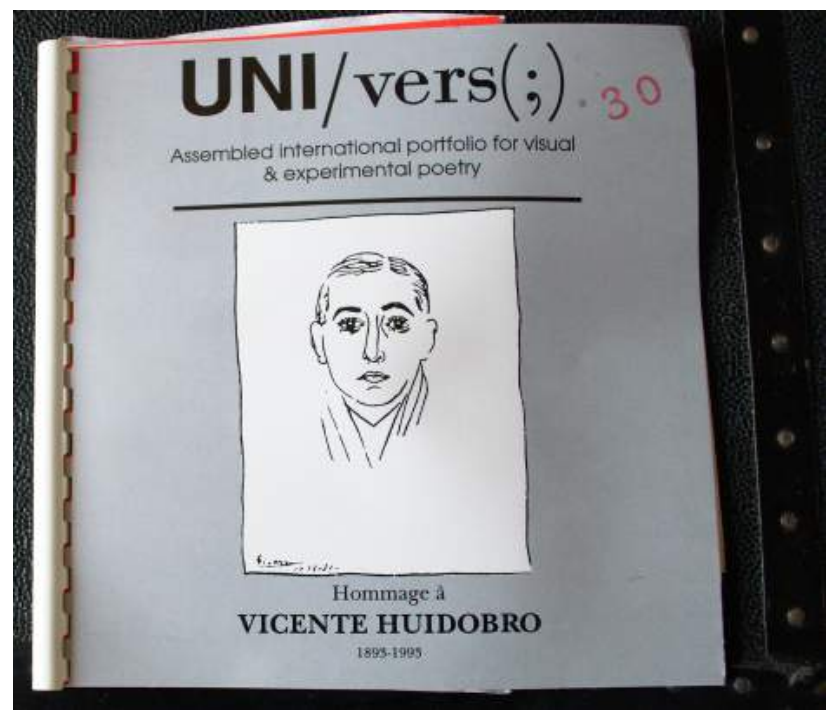

Figura 4: Guillermo Deisler (1993), Uni/vers (;), no. 30, Halle, Edición manual. Fuente: Archivo Deisler.

La obra de Deisler se caracterizó por aspirar a una realización colectiva. Dentro de sus prácticas en el Arte Correo, enviaba proyectos antes que obras, como aquél donde incitaba al lector a interactuar con el libro mediante instrucciones como: corte, ponga una liga, o bote a la basura. Se trataba de un juego que invitaba a manipular de una manera diferente el libro. Para su obra poético visual, se valía del diseño y del icono, en resumen, de los elementos propios de la comunicación de masas, y mediante los cuales podía ofrecer un crítica a la sociedad. En términos generales, podemos decir que sus principales temáticas fueron la crítica social y la reflexión acerca de la misma poesía y la escritura (figura 5).

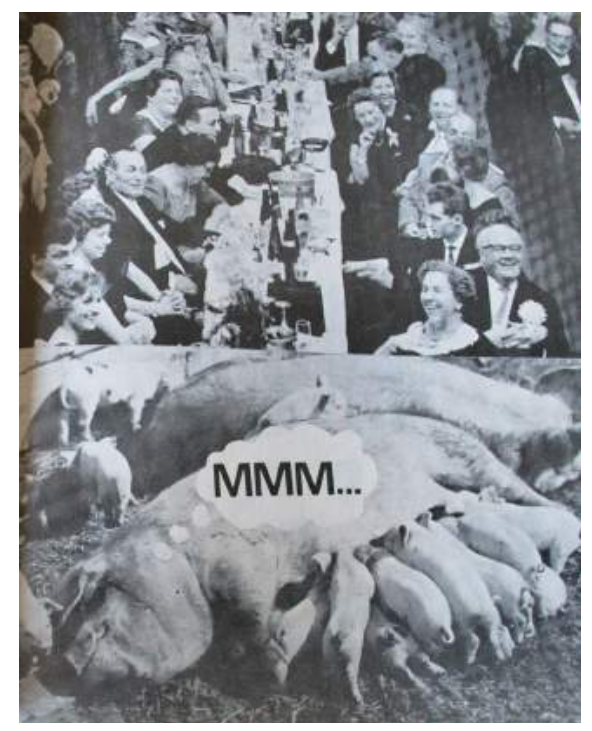


Figura 5. Guillermo Deisler (1972), "Sin título", Poemas visivos y proposiciones a realizar. Antofagasta, Ediciones Mimbre.

Fuente: Archivo Deisler.

Conviene que, de acuerdo con una tipología de los poemas visuales, todos los ejemplos aquí seleccionados corresponden al denominado poema verbal-visual, ${ }^{8}$ lo cual quiere decir que estamos ante una forma un tanto tradicional en la poesía visual que ya tiene determinadas características inherentes, tal como si abordáramos un soneto. Un poema verbal-visual conjuga palabra e imagen, a la vez que intenta que estos códigos disyuntivos entre sí cobren sentido al relacionarse. En síntesis, el poema se construye mediante una red de informaciones cruzadas entre los códigos.

En el caso que nos ocupa en este momento podemos ver que la presencia de lo verbal es mínima, no así la imagen que predomina en el texto. En cuanto a la identificación de líneas y formas, observamos que no hay una manipulación directa de éstas, pues toma un par de fotografías perfectamente identificables, presentadas en blanco y negro, un aspecto típico de la poesía visual de los años setenta y ochenta, debido a la dificultad de la distribución e impresión de materiales a color, además de que en muchos trabajos de este tipo se hacía uso del copy-art. ${ }^{9}$ Así pues, lo importante es la identificación de las formas. Tenemos, por ejemplo, una fotografía de un banquete, donde se ve una hembra porcina alimentando a sus hijos y un globo de pensamiento con la leyenda "MMM...". Este poema presenta una temporalidad aislada, es decir, no posee relación o sucesión temporal entre sus elementos. A un nivel retórico visual, y si acudimos a los usos retóricos generales ${ }^{10}$ propios de la imagen, este texto explota el emparejamiento, es decir, la presencia simultánea de dos figuras diferentes entre sí, cada una con su propio espacio bien delimitado. Regularmente se considera a una como transformación de la otra, pues no hay subordinación o coordinación; se trata de una figura antes que compuesta, sobrepuesta, ya que no se fusiona sino que se amontona. Como podemos observar en este texto, la intención es comparar a las personas del banquete, evidentemente adineradas, con la figura del cerdo. Ello es tomado en un sentido peyorativo, que permite equiparar a la clase alta con los pequeños cerdos, alimentándose y amontonándose en torno a la fuente de la riqueza, con gesto voraz, divertido y fundamentalmente egoísta.

Dentro de su obra, también se incluyen críticas a compañías como la petrolera Esso, como también se dio tiempo en manifestarse por la paz a nivel mundial. De hecho, hay una serie de poemas dedicados a la paz, donde juega con los iconos representativos como el de la paloma. En la muestra siguiente (figura 6), diseña un formulario cuyo espacio en blanco ocupa la mayor parte de la hoja, al final del cual pide la fecha y la firma. El documento es intervenido por Deisler

\footnotetext{
${ }^{8}$ Otras formas del poema visual son: el poema minimalista por concentración, el poema propuesta, el poema acción, el poema objeto, el video-poema y el poema cibernético.

${ }^{9}$ Este concepto se refiere al también llamado xerox-art, es decir, el uso de la fotocopia con fines artísticos y literarios.

${ }^{10}$ Los usos retóricos generales de la imagen de acuerdo con el Grupo $\mu$ son cuatro: las interpenetraciones, los emparejamientos, los tropos y los tropos proyectados.
} 
con la palabra peace en una posición central y destacada en negritas, pero también como fondo aparece la misma palabra como marca de agua, llenando todo el espacio en blanco y poniendo de relieve el mensaje, breve y directo: paz.

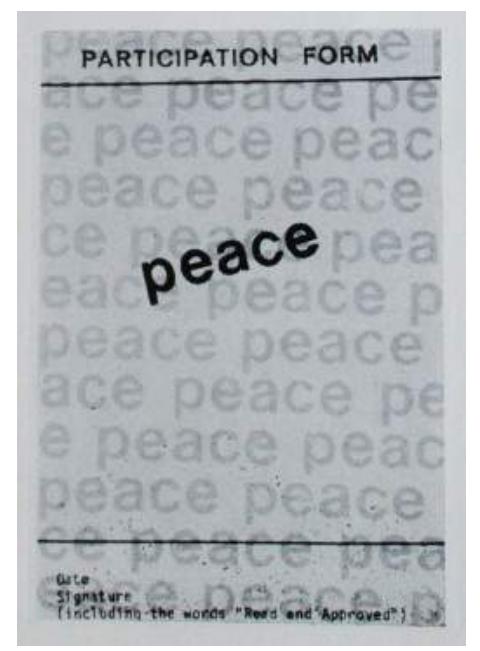

Figura 6: Guillermo Deisler, (1986) "Peace”. Berlin,

"Märkische Volksstimme”. Fuente: Archivo Deisler.

Además de la Antología de poesía visiva aparecida en 1972, en ese mismo año y de la mano de la misma editorial, Ediciones Mimbre, aparece su obra Poemas visivos y proposiciones a realizar, la cual desde la portada apela a la interacción en busca del juego con el libro material. En ella se muestra la silueta de una persona cuyos ojos vienes perforada e intervenidos con una tira de papel, donde aparece la leyenda "POESIA VISUAL: DEISLER", de manera que el lector puede hacer que dicha tira pase entre las perforaciones que evocan los ojos. En esta obra, probablemente la más temprana de Deisler respecto a la poesía visual, destaca la intención de reflexionar sobre temas sociales, pero también sobre el mismo hecho de la poesía, de definirla, de jugar con su escritura. Este aspecto trascenderá a su producción posterior, por ejemplo, en Homenaje a la $A$, que aparece en una compilación francesa de su obra (figura 7).

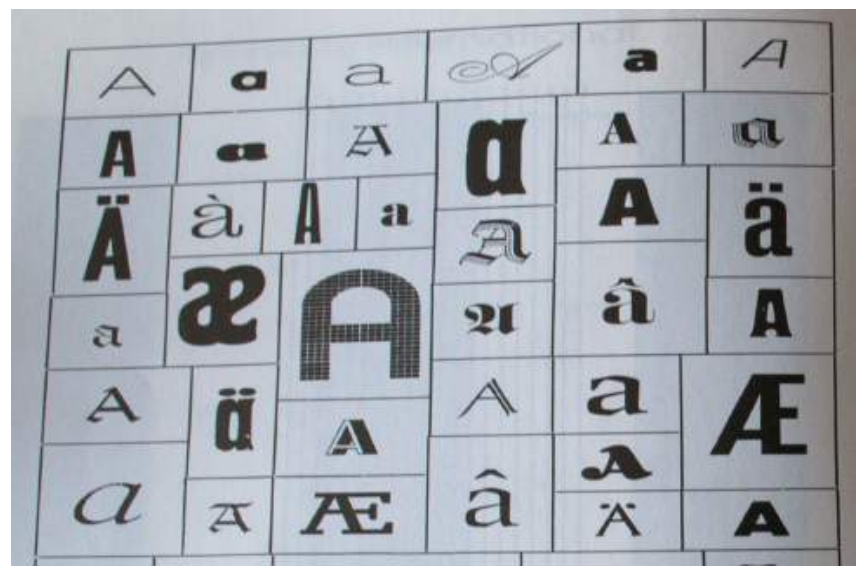


Figura 7: Guillermo Deisler (1998), "Homenaje a A". Halle, Druckhaus Naumburg. Fuente: Archivo Deisler.

En Guillermo Deisler, un compilado póstumo editado en 1998 en Halle, Alemania, se agrupa la mayoría de su obra producida en dicha ciudad. De ahí extraemos un poema (figura 8) que plantea una definición de la poesía. Como la mayoría de sus textos, se trata de un poema verbal visual que entrelaza ambos códigos para transmitir el mensaje. En un análisis de líneas y formas, podemos identificar tanto la parte verbal, POETRY IS POETRY, así como la meramente visual integrada por distintas figuras tales como unas pinzas, un resorte, un sombrero, una campana, una máquina de coser, imágenes de mujeres, herramientas, una sombrilla, una pala, una carretilla y una trompeta, entre otras. Presentado en blanco y negro, a nivel retórico visual se emplea el emparejamiento, vale decir, las imágenes y las grafías guardan una tensión fuerte. A nivel de dimensión o proporción, no se puede establecer que un elemento sea más importante que otro, es decir, que todas guardan una importancia similar en la conformación del texto. La mezcla heterogénea de objetos, este breve collage, puede remitirnos a pensar que la poesía se encuentra en cada objeto y no en ideas determinadas. Si observamos atentamente, puede haber aquí un guiño a la frase de Lautréamont: "Es bello [...] como el encuentro fortuito sobre una mesa de disección, de una máquina de coser de un paraguas" (Lautréamont, 1970: 219).

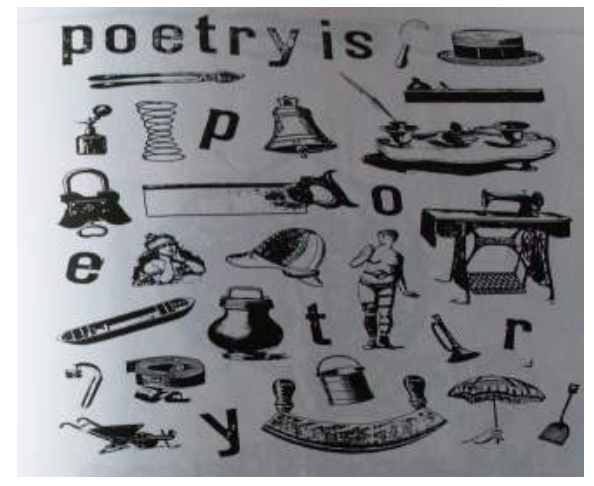

Figura 8: Guillermo Deisler (1998), "Poetry", Halle, Druckhaus Naumburg. Fuente: Archivo Deisler.

Aunque México no estuvo sujeto a la dramática situación de un golpe de Estado, su contexto político y social también determinó la posición artística de las incursiones visualistas en la década de los setenta. El Núcleo Post-Arte surge en un periodo marcado por la matanza de estudiantes y ciudadanos que lleva a cabo el gobierno vía el ejército el 2 de octubre de 1968, hecho vuelto metonimia de la violencia sistemática durante dicha década y la siguiente contra ciertos sectores de la población para acallar las demandas de justicia social. En México, será la época de caída del auge económico, debido sobre todo a la baja en los precios del petróleo. Culturalmente, el Estado mexicano, en un afán por reconciliarse con los sectores abatidos por su política represiva, crea instituciones 
desde donde deriva recursos económicos para el establecimiento de diversos programas de fomento y reconocimiento al arte y la cultura. ${ }^{11}$

La poesía mexicana en los sesenta y setenta será paulatinamente invadida por una nueva generación de autores que crece bajo las propuestas neovanguardistas de Occidente, aunque continúa bajo la fuerte sombra del discurso lírico definido desde los años treinta y cuarenta por los poetas agrupados bajo el nombre de Contemporáneos ${ }^{12}$ y, por otra parte, por la idea de modernidad que Octavio Paz asienta en la importante antología de poesía mexicana Poesía en movimiento (1966). Las incursiones visuales y experimentales, aunque escasas, provienen de una tradición negada por la lírica verbal desde la época virreinal. Así, por ejemplo, encontramos dos antecedentes vanguardistas de gran relevancia durante las primeras décadas del siglo XX en la obra de los estridentistas y José Juan Tablada. Este último representa el puente comunicativo con lo que Mario Enrico Santí denomina "la etapa oriental en la obra de Octavio Paz" (235), la cual corre desde la publicación de Blanco (1966) hasta Topoemas (1968) sin olvidar los Discos visuales (1968): un poema objeto que lamentablemente no se ha reeditado en sus obras completas. Otro antecedente fundamental para el Núcleo Post-Arte lo representa Jesús Arellano (1923-1979), poeta, editor y codirector de la revista Metáfora, una publicación que se distinguió por atacar, desde finales de los cincuenta, al grupo que se reunía en torno a Alfonso Reyes y dominaba el medio literario mexicano. Bajo ese sello editorial, Arellano publicó El canto del gallo. Poelectrones (1972), ${ }^{13}$ cuyo experimentalismo consistió en adaptar el tipografismo derivado de los tipos y la máquina de escribir hacia una computadora, una IBM, desde un procesador de textos para generar poemas figurales y caligramáticos. A decir de Ilana Marek Broid, la escritura de Arellano busca: "iluminar al mundo con veracidad [...] se experimenta, entonces, con la realidad como límite de lo posible, como espacio donde el lector es invitado a ser parte de discursos aún vigentes" (Marek, 2011: 362). El Núcleo Post-Arte deriva entonces de una sólida, aunque marginada, tradición visual que combina la preocupación estética y el deseo de abrevar en otros lenguajes una preocupación social por el entorno inmediato.

Surgidos primero como un colectivo de Arte Correo en 1981, "Colectivo 3", ${ }^{14}$ en 1985 amplía sus horizontes artísticos y cambian al nombre

\footnotetext{
${ }^{11}$ Algunas de estas instituciones son Consejo Nacional de Recursos para la Atención de la Juventud (CREA), Consejo Nacional de los Pueblos Indígenas (CNPI), Consejo Nacional para la Cultura y las Artes (CONACULTA), la revista Tierra Adentro y, posteriormente, el programa de fomento editorial.

${ }^{12}$ Para una mejor comprensión de la influencia del grupo Contemporáneos en la poesía mexicana del siglo XX puede consultarse el trabajo crítico de Anthony Stanto, principlamente: Inventores de tradición: ensayos sobre poesía mexicana moderna, Ciudad de México: El Colegio de México, 1998; "Los Contemporáneos y el debate en torno a la poesía pura”, en Olea Franco, Rafael y Stanton, Anthony (coords.), Los contemporáneos en el laberinto de la crítica, Ciudad de México: El Colegio de México, 1994, pp. 27-44.

${ }^{13}$ En 1975 se reeditó la obra, dado que Arellano contó con otro tipo de computadoras que le permitieron perfeccionar la técnica de elaboración así como aumentar el número de textos.

${ }^{14}$ En el libro de César Espinosa y Araceli Zúniga, La Perra Brava, Arte, crisis y políticas culturales, se da cuenta del contexto y la génesis de su colectivo, la cual se remonta a la década de los setenta, vinculado al taller literario y revista Mester de Juan José Arreola. Posteriormente,
} 
de "Núcleo Post-Arte" para producir su obra contra "la desilusión (el ocaso de las viejas ilusiones) o el silencio arrogante ante el fin de la historia: el holocausto ecológico-nuclear" (Núcleo Post-Arte, 1987: 6). Así como Juan Luis Martínez tacha su nombre en un acto de borrar la función autoral de una obra, los miembros de Núcleo Post-Arte conciben la producción artística como un proceso social que diluye al genio individual como epítome del modelo económico capitalista. El arte es un acto de protesta que desde el mismo proceso debe dejar patente las estructuras ideológicas:

Es preciso romper el espeso silencio y difundir en México las investigaciones y experimentaciones encauzadas a la integración/síntesis de los lenguas artísticos, pero buscando formas de muestreo y circulación que tiendan a su socialización popular, además de evitar la entrega de plusvalía ideológico-simbólica a las agencias del capitalismo monopólico y trasnacional, con su red tentacular en la industria de la cultura. (Núcleo Post-Arte, 1987: 6)

Teniendo como modelo el movimiento brasileño de Poesía concreta, el Núcleo Post-Arte se involucra en la intensa promoción y difusión de visualismos y experimentaciones literarias a través de las Bienales de Poesía Visual y Experimental llevadas a cabo entre 1985 y 2004 en México. Coordinados por César Espinosa, en un inicio se integraron artistas plásticos que incursionaban en un arte más híbrido para descentrar a la palabra y convertirla en un significante más de la realidad: una propuesta que de alguna manera empata con la denuncia logocéntrica de Jacques Derrida. El Núcleo Post-Arte se visibiliza a través de la "Primera Bienal Internacional de Poesía Visual y Experimental en México (1985-1986)", donde se convoca a artistas de todo el mundo: "El canal fue la red mundial de arte-correo y se aplicaron también sus reglas implícitas: todo se exhibe, no hay jurado de selección ni pago de derechos por exponer, como tampoco premios ni distinciones personales o a tendencias estéticas" (Núcleo Post-Arte, 1987: 5). En esta primera convocatoria, aparecían como firmantes, además de César Espinosa, Leticia Ocharán, Araceli Zúñiga, María Eugenia Guerra, Cosme Ornelas y Jorge Rosano.

Bajo este marco crítico general se establece una vía de lectura para algunos de los trabajos del Núcleo Post-Arte que mostramos a continuación. ${ }^{15}$

César Espinosa y Andrés González Pagés trabajarán en el proyecto de una revista "protoconceptualista” titulada La Perra Brava. Sin éxito para la publicación, Espinosa con Zúñiga pasaron a integrar "El TAco de la Perra Brava (TAco: Taller de arte y comunicación)". Luego, desde 1976, trabajaron con varios colectivos y grupos culturales experimentales bajo el nombre de "El Colectivo", inmediato antecesor de "Colectivo 3".

${ }^{15}$ En contraste con la creciente crítica sobre Guillermo Deisler, el Núcleo Post-Arte no ha contado con mucha atención salvo: las propias autorrefencias en sus compilatorios sobre las Bienales de Poesía Visual y Experimental, la tesis de licenciatura "El arte correo en México: Origen y problemática en el periodo de 1970 a 1984" de Mauricio B. Guerrero Alarcón (1986), Licenciatura en Artes Visuales, UNAM; Mauricio Marcin (2011), Arte Correo. Ciudad de México /Barcelona: RM/RM Verlag, 2011; el ya citado capítulo de Alejandro Palma Castro (2011); la tesis de maestría "Poesía visual en México a finales del siglo XX" de Gabriel Hernández Espinosa (2013), Maestría en Literatura Mexicana, BUAP; y Fernanda Nogueira (abril 2014), "Revolución: Un poema colectivo. Potencias poético-políticas de la red de Arte Correo III", en Post. Notes on Modern \& Contemporary Art Around the Globe. Consultado 
Quizás uno de los trabajos más representativos sea "Nueva Business Class sobre la mesa" (figura 9) de César Espinosa. Desde la misma propuesta de manufactura, resulta revelador que el proceso esté sujeto a una diacronía de su evolución, pues se trata de una obra que se transforma conforme la tecnología va haciendo más accesible los mecanismos de reproducción. En su primera versión para la Segunda Bienal (1988), "Nueva Business Class sobre la mesa", la propuesta del cartel era en blanco y negro. ${ }^{16}$ Recordemos que parte del cometido de este tipo de arte es también social y en lugar de acudir a sofisticadas técnicas de arte, tendían a un "arte de bases sin artistas, aprovechando los 'recursos de la pobreza'” (Núcleo Post-Arte, 1987: 7). Como parte del trabajo con el mismo soporte, que trasciende la hoja de papel y el libro como objeto de lo poético, se propone el cartel como medio difusor del poema elaborado a través de técnicas como el offset, la fotocopiadora, el dibujo y el montaje. Su tránsito estaba pensado a través de la red de Arte Correo y, por lo tanto, no existe una sola obra sino una serie de reproducciones que rebaten la idea de originalidad e irreproducibilidad del arte. El efecto poético de este poema objeto, entonces, desafía la noción romántica que caracteriza a la poesía lírica: individual, única e irrepetible y, por tanto, enmarcada en un tiempo y espacio "poéticos" (hic et nunc) ajeno al tiempo histórico. La propuesta que maneja Espinosa se vincula con la trascendencia de un momento histórico para el arte, pues de acuerdo con Fabiene Pianowski "En la década de los setenta, el arte correo llegó a ser considerado por algunos (muy pocos) críticos e historiadores de arte como uno de los grandes fenómenos de la vanguardia internacional" (Pianowski, 2013: 111).

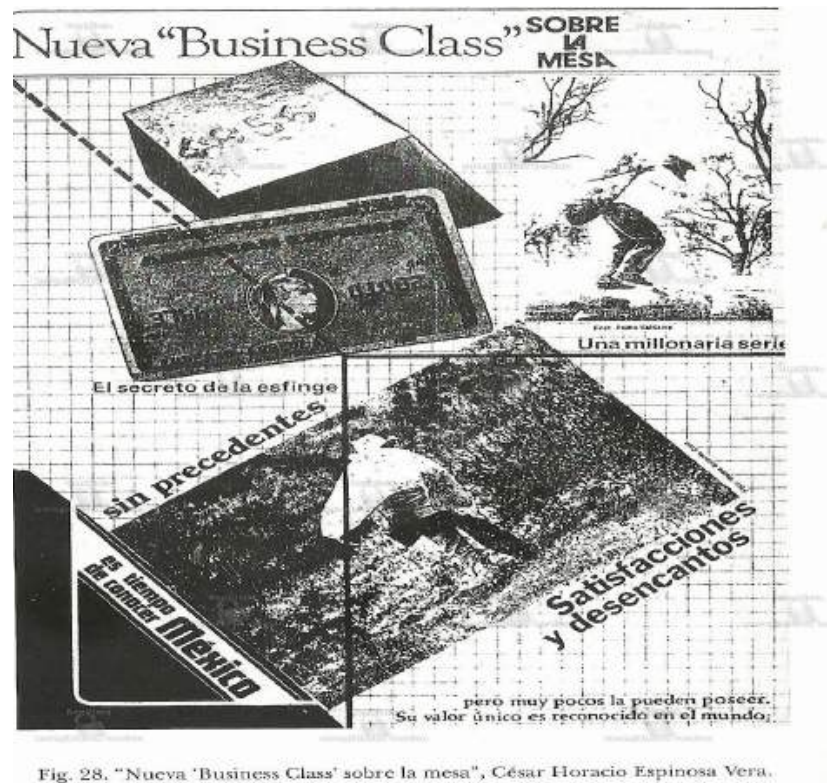

Figura 9: César Espinosa (1988), "Nueva Business Class". Fuente: Espinosa, César (1988), "Nueva Business Class", en Espinosa, César

en <http://post.at.moma.org/content_items/440-revolucion-un-poema-colectivo-potenciaspoetico-politicas-de-la-red-de-arte-correo-iii> (27 de marzo 2017).

${ }^{16}$ Posteriormente, gracias al apoyo de la red de Internet como medio de comunicación, Espinosa aumentó color a ciertos elementos con el propósito de lograr un mayor contraste. 
(comp. y org.), Poemex 2. Segunda muestra de Poesía Visual/ Experimental / Alternativa Mexicana. México D.F., Secretaría General de Desarrollo Social.

En lo que respecta a otros elementos que nos interesa destacar sobre "Nueva Business Class sobre la mesa", está la correspondencia entre forma y contenido, así como su mensaje de denuncia social. En general, el cartel se encuentra conformado como una parodia a los anuncios publicitarios donde reproduce slogans y busca colocar los elementos de una manera que la atención visual vaya haciendo un recorrido de lo denotativo a lo connotativo. En un texto programático, "Los signos corrosivos: por una escritura liberadora", Espinosa hace la siguiente propuesta:

Desde la crítica del discurso clásico y en los límites del lenguaje, la experimentación poética hace hincapié en el origen material de la poesía, palpable y manipulable, como un objeto construido y dotado de leyes propias. Derogadas las atmósferas herméticas y la expresión de una sensibilidad autista, al menos en sentido programático o "función metalingüística", los procedimientos emergentes comprenden: verso suelto, ideograma, espacio geográfico, montaje, fragmentación, transposiciones temporales, creación de estructuras lingüísticas, de movimiento, de organización, etcétera. (Espinosa, 1987: 17; cursivas del original)

Es así como este collage se recontextualiza en el ámbito neovanguardista que da origen al Arte Correo, pero además se enmarca en una agenda propia que denuncia las desigualdades económicas que el sistema capitalista ha provocado en México. A través de la descontextualización de significados (un lingote de oro, una tarjeta de crédito, la fotografía de un campesino), y su recontextualización como significantes para crear una nueva realidad, Espinosa transforma el mensaje publicitario en un mensaje de denuncia. Por medio del contraste, evidenciado en formas, texturas y contenidos, así como en los mensajes verbales, Espinosa pasa a crear una nueva ruta de lectura que podría ser la siguiente: en la historia de la humanidad, desde los egipcios, ha existido un sistema basado en la explotación de la mayoría que pondera el valor económico sobre el valor humano, México se encuentra expuesto ante este sistema, sin embargo, deberá ser tiempo de conocer al país desde abajo y a la izquierda. "Nueva Business Class sobre la mesa" pone el proceso artístico en función de un mensaje de denuncia. Se trata de un arte comprometido con la exploración de nuevas formas expresivas, como medio para combatir los desastres de la ideología capitalista.

Otra integrante del Núcleo Post-Arte, Leticia Ocharán, también presenta un objeto artístico hacia la vía de la denuncia, aunque en esta ocasión, no tanto lo social como lo político. "Ay" (figura 10) es un poema que guarda profunda relación con la Poesía concreta y la articulación semiótica de los signos entre los cuales se encuentra la palabra como uno más. Precisamente, al considerar que estos poemas visuales dislocan la parte verbal del discurso poético, nos parece sumamente ilustrativo este caso. Por medio de una imagen 
secuencial se sugiere un movimiento pendular, que revelará a Sudamérica en un acercamiento. Dicho movimiento suplanta el ritmo de verso para expresar una imagen secuencial que irá hasta lo más profundo o lejano. El proceso del ritmo creciente como mediador de la sensación poética se sustituye con lo visual, en tanto se muestra un acercamiento paulatino. El poema se reproduce en la memoria de la Segunda Bienal junto con un texto de Ocharán, "El sujeto por el verbo", donde brinda una explicación de su poema objeto:

El tratamiento visual que les otorgo a dichas partículas está sustentado en la inversión del plano significativo, al permutar su carácter verbal —en tanto que sugiere un acto- por la del sujeto. $A y$, por ejemplo, no es entonces una exclamación sino un personaje sobre el que recae una acción que provoca lo que comunica su nombre. De esta manera, $A y$ se convierte en un receptor o emisor. (Ocharán, 1988: 16)

A esta consideración, habrá que agregar además que la interjección "Ay" ha sido por antonomasia un elemento del discurso lírico, en virtud de su utilización para significar un estado sentimental. El vocablo conduce a una experiencia por parte del receptor, es el vehículo de la sensación. Ocharán descontextualiza esta función y coloca al centro de la secuencia la onomatopeya para convertirla en el sujeto enunciativo, el cual por medio de un proceso de interpretación analógico expresa el sentimiento de dolor en Sudamérica derivado de las dictaduras que asolan a la mayoría de esos países. Así como en los Artefactos visuales de Parra, Ocharán infiere que el medio debe ser el mensaje. De manera aguda, al desarticular la única palabra que existe en el poema y convertirla en un signo visual que incluso es maleable a una textura, habría que ver el diseño del primer cuadro como un signo del terror, para transformarse en una idea.

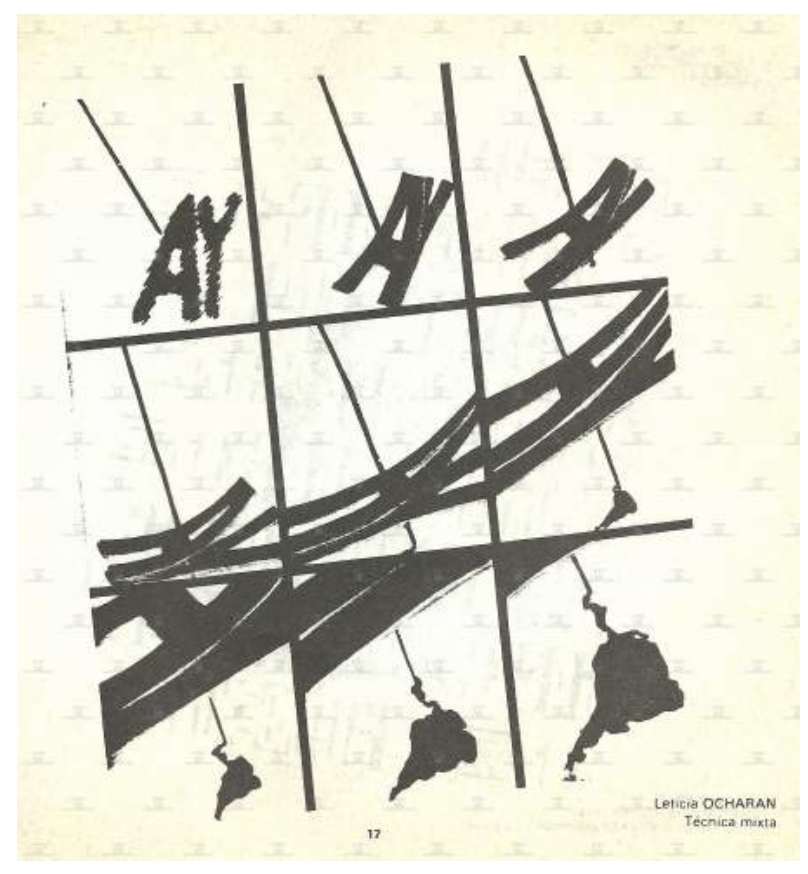


Figura 10: Leticia Ocharán (1988), “Ay".

Fuente: OCHARÁN, Leticia (1988), “Ay” en Espinosa, César

(comp. y org.), Poemex 2 Segunda muestra de Poesía

Visual/Experimental/ Alternativa Mexicana. México D.F., Secretaría

General de Desarrollo Social.

Hemos realizado una breve y fragmentada revisión de lo que son los visualismos surgidos en Chile y México durante la década de los setenta y ochenta, porque consideramos que su carácter experimental e híbrido los ha relegado del sistema literario debido a la fuerte tradición verbal impuesta en el discurso poético de esos países. La poca atención crítica a la obra de Guillermo Deisler y el Núcleo Post-Arte guarda una estrecha relación con el lugar desde donde se enuncia. A partir de la topoiesis de las instancias enunciativas, nos parece oportuno interpretar comparativamente los lugares de enunciación tanto de Deisler y el Núcleo Post-Arte. En ambos casos, esta situación comunicativa viene mediada por la particularidad en el proceso creativo.

El "repertorio temático formal" desafía, en ambos casos de estudio, al canon de la poesía chilena y mexicana que, al decir del Núcleo Post-Arte, representa un influjo, desde las primeras décadas del siglo XX (Neruda en Chile y los Contemporáneos en México), sobre el "qué-hacer" y "cómo-hacer" (Núcleo Post-Arte, 1987: 6). La elección de cierto repertorio temático formal representa "una forma del discurso literario dentro del repertorio que le brinda el tiempo y el espacio, la época o el lugar, en el que y desde el que escribe, ya sea para continuar o romper con la tradición. Esta decisión también admite un modelo de mundo que conserva y legitima, subvierte y revoluciona, o desea restaurar" (Escobar, 2017: 32). Como hemos analizado en ambos casos, sus producciones artísticas provienen del desencanto y desconfianza con una realidad inmediata: un golpe de Estado en el caso de Deisler y una represión sistemática del gobierno contra ciertos sectores de la población para los miembros del Núcleo Post-Arte. Esto los obliga a adoptar una postura radical contra la poesía verbal como eje canónico. La estrategia en ambos casos ha sido partir de los elementos visuales de otras artes para, desde dichos fundamentos, vaciar el poder del significado de las palabras y convertirlas en signos que se suman a un complejo de signos de otro tipo. Tal procedimiento, comúnmente conocido como descontextualización, subvierte el valor simbólico de la poesía, como revisamos incluso en los antecedentes que circundan a estos artistas, suele ser el poeta quien a partir de su reflexión y genio incursiona en un experimentalismo con lo verbal (Nicanor Parra, Octavio Paz).

Mencionábamos líneas arriba que la situación de estos artistas los "obligaba" a adoptar una postura específica. Creemos no exagerar en ambos casos, pues al evitar los medios convencionales de expresión y sus prácticas legitimadoras, y tomando en cuenta su postura ideológica, la cual incluso le vale a Deisler ser encarcelado por la dictadura pinochetista, las opciones no son muchas. Dentro de esta topoiesis de la situación comunicativa, veremos que el tipo de espacio desde donde se desarrolla esta propuesta visual viene condicionado por una ideología particular que busca deconstruir el logocentrismo, desconocer algunos fundamentos del discurso poético como los 
únicos productores de la experiencia estética y comunicar el desencanto que produce el sistema político y social imperante. Ante esto, es evidente que sobre todo lo verbal tenga que dislocarse del discurso poético a través de los fundamentos del letrismo, pero considerando la reproducción tipográfica a través de ciertas máquinas capaces de recordarle al lector que las palabras son eso precisamente: un conjunto de letras producidas por una máquina y no la esencia de lo poético. Clemente Padín, uno de los creadores y crítico más destacado del siglo XX de la poesía visual y experimental, escribía en su "Manifiesto de la nueva poesía": "El lenguaje rompe con la tradición lingüística que se ha empecinado en definirlo por su función y no por su primaria condición de objeto. Guerra a la exclusiva y autoritaria función expresiva del lenguaje" (1969: 2). En la contexto de las neovanguardias, Padín parece hacer eco de lo que muchos poetas y artistas visuales de la segunda mitad del siglo XX vienen reflexionando sobre la imposibilidad del lenguaje para referir al objeto, o más bien a una realidad representativa de éste. El encontronazo con el desencanto político terminará por hacer el resto, pues si las historias oficiales a través de un lenguaje hegemónico tratan de imponer el olvido y una memoria apócrifa, entonces no queda más que generar un nuevo lenguaje que pueda ser comprendido e interpretado por el lector general de su tiempo. Ocharán en "Ay" es una muestra clara de dicho procedimiento.

Finalmente, nos parece relevante retomar la topoiesis del esquema de comunicación ${ }^{17}$ recordando que tanto el trabajo de Deisler como el del Núcleo Post-Arte se genera en un principio bajo la idea del Arte Correo. Esto condiciona que el mensaje sea determinado en primera instancia por su forma, pero también, a nivel temático, a partir de un ethos. ${ }^{18}$ Ya hemos discutido antes la estrategia formal de estos poemas como producto de su contexto político y social. Queremos pasar ahora a exponer la estructura retórica de estos textos que subvierten al logos para orientarlo, en lugar de hacia un pathos o búsqueda de un sentimiento colectivo, hacia un ethos como fuente de comunicación con el lector. La importancia comunicativa de estas obras subraya la idea de conformar una comunidad. El Arte Correo tenía como propósito no solamente

\footnotetext{
${ }^{17}$ A plantear de Escobar: "A partir del propio enunciado es como se puede establecer la construcción de un significado desde un contexto particular. Recordemos que la interacción entre locutor y locutario está mediada por un esquema o marco conformado por parámetros como la intención, las representaciones psicosociales, los preconstructos culturales, el ethos y las pasiones transpuestas en la argumentación para generar un micro universo particular" (2017: 32-33).

${ }^{18}$ Para desarrollar este punto interpretativo, nos parece de utilidad citar un artículo de Pere Ballart, "Una elocuencia en cuestión, o el ethos contemporáneo del poeta", que si bien se enfoca en la poesía espańola, creemos que en sus consideraciones generales es aplicable a nuestros casos de estudio. Ballart menciona que el poeta de nuestro tiempo se encuentra condicionado por las circunstancias sociales y literarias de la modernidad, "por cuanto afecta al modo en que la voz que habla en el poema consigue (o no) erigirse en instancia significativa y llegar a establecer (o no) una potencial comunicación con el conjunto de sus lectores" (2005: 75). Si usualmente en la poesía lírica el ethos se subsumía al pathos, en la poesía moderna el desgaste y la falta de confianza en la realidad que sostiene al sujeto hablante, ha provocado que este busque en la retórica un tono conciliador para persuadir al lector y ganar de nuevo su confianza. Es ahí donde debe constituirse un fin ético concatenado con las aspiraciones del lector.
} 
difundir en redes una propuesta de comunidad, sino que como establece Pianowski:

La actuación en redes de intercambio alternativas confiere a las operaciones del arte correo un estatus de colectividad, que funcionaban en aquel momento subversivamente como una guerrilla subterránea y rizomática de ideas y conceptos ético-estéticos. La red postal se convertía entonces en un lugar de asociaciones temporales donde el arte y la política se encontraban. (Pianowski, 2013: 75)

Es así como Deisler, Espinosa y Ocharán plantean un espacio donde se combina un concepto estético —el emparejamiento en "MMM", "Nueva Business Class sobre la mesa" o la interpenetración en "Ay" - con uno ético, a través del contraste o una secuencia sintagmática de acercamiento al objeto. El resultado de lectura general provocará que el sujeto enunciativo del poema se comunique directamente con una comunidad dentro de la cual se expresan los mismos sentimientos $y$, por tanto, se solidariza con dicho mensaje. El autor logra, como dice Ballart:

Levantar un perfil de confianza, encontrar una voz segura y firme, construir, en definitiva, una identidad poética capaz de asumir lo que los versos declaran [...] tal es la cifra hoy del éxito comunicativo de un poema, que descansa más en un componente de adecuación, verosimilitud y credibilidad, esto es, de persuasión, que en cualquier supuesto expresivo que haga de la efusión sentimental o de la imaginación visionaria el puntal simbólico del poema. (Ballart, 2005: 76; cursivas del original)

El espacio que recompone este esquema de comunicación es uno de confianza hacia el acto poético, en un entorno pleno de incertidumbre y desencanto.

Las conclusiones que nos permite establecer este análisis e interpretación de la poesía visual enmarcada en el Arte Correo, surgido en Chile a partir de Deisler y en México con el Núcleo Post-Arte, tienden a reconocer el cambio de dirección que hasta entonces había operado en los experimentalismos visuales de la poesía. Si en las vanguardias históricas y todavía en la década neovanguardista de los sesenta en Chile y México se trataba de poetas incursionando en lo visual, en los setenta y ochenta la base proviene de artistas visuales que aplican los procedimientos del diseño gráfico, desde el uso de la retícula hasta la apropiación del collage, como método compositivo. Según hemos planteado en el caso de Deisler, si bien antes de su exilio comenzaba a ubicarse como un poeta visual, el cisma del golpe de Estado, su encarcelamiento y salida del país, lo obligaron a replantearse una revisión del proceso mismo del sistema literario y sus formas de legitimación. Podemos dar cuenta de este cambio a través de la semblanza y entrevista de Ariel Santibáńez en 1971, cuando ante la pregunta de si la poesía visual vendría a terminar con la poesía escrita, Deisler contestó: "No creo; hay un desplazamiento, por ahora. No está muy claro que podamos reemplazar lo escrito. Además, sigue siendo el punto de partida. Lo que hacía falta era un remezón fuerte al verbalismo literal de la poesía" (Santibánez, 1971: 17). Si antes de su exilio, la poesía visual le 
parecía apenas una sacudida al "verbalismo literal de la poesía", con el curso de su estancia y trabajo en Europa habrá de reflexionar en "Algunos hechos que considero importante (sic) en mi biografía": "Más que a la fuerza de la palabra escrita le he otorgado una importancia al hallazgo, a la invención, al trastrueque innovador, a la decodificación y a la desmistificación (sic)" (Deisler, 1990: s/p). Por consiguiente, ya no se trata tanto de un "remezón" como una "decodificación" y "desmitificación" capaz de dislocar definitivamente el sentido de lo poético en la poesía.

En esa dislocación también fue relevante la apropiación de herramientas tecnológicas, como el caso del uso del offset o la fotocopia, las cuales relativizaron el peso del libro como dispositivo por antonomasia del discurso poético. Por ejemplo, Deisler, quizás en concordancia con la propuesta del libro de artista de Vicuńa o Martínez, realiza un trabajo artesanal con la creación de sus carpetas de artista para la distribución a nivel mundial. Espinosa trabajó en una mejora de diseño de su "Nueva Business Class" y, además de la red existente de Arte Correo, su trabajo se extendió hasta Internet haciendo evidente la relación estructural entre las redes de Arte Correo y esta nueva tecnología de comunicación. Se trata de formas menos solemnes o trascendentales, derivadas del lugar desde donde se enuncian, y cuyo fin fue transmitir un modelo de mundo distinto al impuesto por medio de la violencia del Estado y sus instituciones.

El tema capital de la poesía visual tanto en Chile como en México, y que hemos revisado hasta aquí, se encuentra orientado hacia la crítica política, social y cultural. Se denuncia la violencia y las prácticas legitimadoras tanto de los gobiernos como del sistema capitalista, las cuales condicionan incluso el campo del arte. Dada la concisión y agilidad del mensaje en esta poesía, se logró una rápida comunicación con el receptor, pues su retórica se elaboró orientada hacia la conformación de un ethos que empatizara con la necesidad expresiva del contexto de un golpe de Estado en Chile y la represión del gobierno a varios sectores sociales en México. Destacan Deisler y Espinosa como dentro de los pocos poetas visuales y experimentales que se cuestionaron y reflexionaron sobre el quehacer poético experimental desde la creación, pero también desde la teoría. Definitivamente, ahora que los tiempos han cambiado en ambos países, y la experimentación con otros elementos además del verbal se ha vuelto moneda corriente para las nuevas generaciones, es necesario rescatar y reeditar los trabajos de estos y otros críticos y artistas de la poesía visual en Latinoamérica, quienes a lo largo de la segunda mitad del siglo XX impulsaron otras formas de crear poesía además de la verbal. Sus documentos deben ser el testimonio de una tradición que aún nos negamos a reconocer, en cuanto seguimos atados a la concepción de un discurso poético predominantemente verbal y ajeno al entorno inmediato. Varios procesos políticos y sociales de la actualidad en Latinoamérica están haciendo inevitable el dislocamiento de lo verbal en la poesía. En tal sentido, tanto Deisler como el Núcleo Post-Arte son el testimonio de un camino andado. 


\section{BIBLIOGRAFÍA}

BALlart, Pere (2005), "Una elocuencia en cuestión, o el ethos contemporáneo del poeta", en Signa. Revista de la Asociación Española de Semiótica, n. ${ }^{\circ}$ 14, pp. 73-104.

Movimiento NS (Nueva SOlIDARIDAD), (1964), "Primer encuentro americano de poetas. Declaración de México", en El corno emplumado, n. ${ }^{\circ}$ 10, pp. 112-116.

De Campos, Agusto; Pignatari, Décio y De Campos, Haroldo (1975 [1958]), "Plano-piloto para poesia concreta", en Teoria da poesía concreta. Textos críticos e manifestos 1950-1960. São Paulo, Livraria Duas Cidades, pp. 156-158.

DeISLER, Guillermo (2015), "Publicaciones de Deisler" en Archivo Guillermo Deisler. Sitio oficial del artista visual chileno Guillermo Deisler (19401995). Consultado en <http://guillermodeisler.cl/publicaciones/de-deisler/> (27 de marzo 2017).

(2009), "Algunos hechos que considero importante en mi biografía”, en Archivo Guillermo Deisler. Sitio oficial del artista visual chileno Guillermo Deisler (1940-1995).

Consultado

en <http://guillermodeisler.cl/publicaciones/de-deisler/> (27 de marzo 2017).

Escobar Fuentes, Samantha; Ríos Baeza, Felipe; Sánchez Carbó, José; Ramírez Olivares, Alicia; Palma Castro, Alejandro y Ramírez LÁMBARRY, Alejandro (2017), "Topoiesis de las instancias enunciativas", en Romance Quarterly, vol. 1, n. ${ }^{\circ}$ 64, pp. 28-36. DOI: <http://www.dx.doi.org/10.1080/08831157.2017.1254480>.

Espinosa, César; Zuñiga, Araceli (2002), La Perra Brava: Arte, crisis y políticas culturales. Ciudad de México, UNAM.

FABI, Sauro (2008), L'avanguardia per tutti: concretismo e poesia visiva tra Russia, Europa e Brasile. Italia, Edizioni Università di Macerata.

MADRID LETELIER, Alberto (2007), “'Salón de Otoño': Las hojas que faltan”, en Vicuña, Cecilia, Otoño = Autumn. Santiago de Chile, Museo Nacional de Bellas Artes, pp. 5-12.

MAREK BROID, Ilana (2011), "A la luz del tiempo, un acercamiento a la poesía visual de Jesús Arellano”, en Gordon, Samuel (comp.), La Poesía Visual en México. Toluca, UAEM, pp. 323-379.

MarTíneZ, Juan Luis (1985), La nueva novela. Santiago de Chile, Ediciones Archivo.

Núcleo Post-Arte (1986), Primera Bienal Internacional de poesía visual y experimental en México 1985-1986. Ciudad de México, Dirección General de Difusión y Relaciones Públicas del Departamento del Distrito Federal.

(1987), "Palabras clave", en Espinosa, César (comp. y org.), Signos Corrosivos. Selección de textos sobre poesía visual-concreta-experimentalalternativa, Ciudad de México: Editorial Factor, pp. 5-7.

OCharán, Leticia (1988), “Ay” en Espinosa, César (comp. y org.), Poemex 2 Segunda muestra de Poesía Visual/Experimental/ Alternativa Mexicana. México D.F., Secretaría General de Desarrollo Social. 
(1988) "El sujeto por el verbo", en Poemex 2 Segunda muestra de Poesía Visual/Experimental/ Alternativa Mexicana. México: Secretaría General de Desarrollo Social.

PAdín, Clemente (1969), "Manifiesto de la nueva poesía”, en Ovum 10, n. ${ }^{\circ}$ 1, pp. 2 y 23.

PAlma CASTRO, Alejandro (2011), “Tentativa para la tradición de una poesía visual en México" en Gordon, Samuel (comp.), La Poesía Visual en México. Toluca, UAEM, pp. 165-250.

; SÁnchez Carbó, José; Ramírez Olivares, Alicia; Ríos Baeza, Felipe; Escobar Fuentes, Samantha y Ramírez LÁmbarry, Alejandro (2017), "Topoiesis: Procesos de espacialización en la literatura (crítica y metodología)", en Romance Quarterly, vol. 1, n. ${ }^{\circ}$ 64, pp. 1-12. DOI: <http://www.dx.doi.org/10.1080/08831157.2017.1254467>.

PIANOWSKI, Fabiene (2013), Análisis histórico del arte correo en América Latina. Barcelona, Universitat de Barcelona.

RICHARD, Nelly (1994), "Una cita limítrofe entre neovanguardia y postvanguardia", en La insubordinación de los signos: (cambio político, transformaciones culturales y poéticas de la crisis). Santiago, Cuarto Propio, pp. 37-54.

SANTí, Mario Enrico (ed.) (1995), Archivo Blanco. Ciudad de México: Ediciones del Equilibrista/ El Colegio Nacional.

SANTIBÁÑEZ, Ariel (1971), "La visión mágica de la madera. Los gruñidos de la imagen actual. El libro como unidad artesanal. Guillermo Deisler, al paso", en Tebaida, n. ${ }^{\circ}$ 6, pp. 16-18.

VALDIVIESO, Jaime (2001), "Juan Luis Martínez: adiós a la cordura”, en Fariña, Soledad y Hernández, Elvira (eds.), Merodeos en torno a la obra poética de Juan Luis Martínez. Santiago de Chile, Intemperie, pp. 54-61.

ViCuÑA, Cecilia (1973). Sabor A Mi. South Cullompton: Beau geste press. 